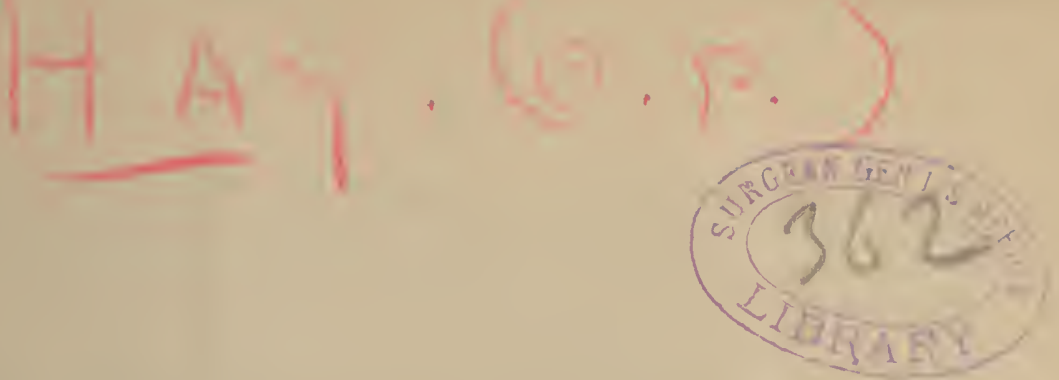

\title{
THE AMPHIBIANS AND REPTILES OF INDIANA.
}

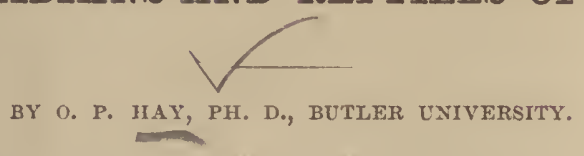

It is the purpose of the writer to give, in the following pages, a brief account of all the AMPHibians and REPTILES, which are either known to have been found, or which, from their occurrence in neighboring States, are thought likely hereafter to be found within the limits of the State of Indiana. This is done with the view partly of imparting to farmers and others some useful information concerning these animals, and partly of indicating to those interested just what species and varieties are known to occur within our territory and what ones need yet to be lnoked for. At the end of the paper I have added a "key" that will enable the collector to determine the species.

Briefly, let us consider some of the reasons wlyy these animals should receive our attention. "Reptiles" are to most people objects of supreme disgust, and such persons can not conceive why any one should study them, or do anything else with them except destroy them from the face of the earth. There are, of course, reasons for this sentinent. Some are dangerous, and these are not well distinguished from the harmless species, which have thus to suffer for being found in bad company. The useful qualities of many kinds are not known or sufficiently valued. Prejudices instilled into our minds from our earliest childhood have much to do, especially with our hatred of snakes. They are made responsible for certain unfortunate occurrences far back in the early history of our race, and every man and boy regards himself as divinely commissioned to execute the sentence that was pronounced on the offender and his supposed descendants.

We should study the phenoniena of nature ont of pure love for them; out of reverence for the Maker of all things, showing it by our reverence for the works of his liands; and out of a desire to aid science in determining the relations that obtrin among existing things and what relations these have with the things of times long past. Further, we should study natural objects in order that we may discover what ones we may make useful for our own purposes, and what ones may be useless or even dangerous to us. Nor is the study of natural things, and the making of discoveries, the exclusive privilege of those who liave received a scientific training. There is not a farner boy in Indiana who may not make solid contributions to science if he will but use his opportunities. Persons who live in the country are in direct contact with nature. They sce a thousand things that the naturalist would delight to see, and yet may never be permitted to behold. The times of coming and going of the various species of birds; their curious habits, as shown in nest-building and obtaining food; and the occurrence here and there of rare species of various animals, are examples of matters which all may observe and report and which science needs to know. 
Many amphibians and reptiles are of direct value to man. Many, as various kinds of turtles and frogs, are used as food, and such miglit even profitably be bred for that purpose. Many others are useful because of their propensity for devouring insects, mice and rats, that are the pest of the farmers. A few, indeed, are dangerous; but it is worth any person's efforts to study our reptiles, if for no other reason than to be freed from constant fear of them. Of nearly a hundred species of amplibians and reptiles to be found within Indiana not more than three or four are poisonous, and these are of rare occurrence. The banded or timber rattlesnake, the prairie rattlesnake, and the copperhead comprise the number, unless, perhaps, the deadly water moccasin of the South may be found in the soutliwcstern corner of the State. Some others may strike, or bite a little, or constrict, as they have a right to do, but they are not venomons and can do little hurt. Snakes that roll along like loops, snakes that blow poison, snakes that sting with their tongues or the tips of their tails, and snakes that live for weeks in peoplc'e stomachs, are creatures of the imagination. Therefore, considering their usefulness as destroyers of vermin, no amphibian or reptile ought to be killed, unless it is to lee employed for practical uses or preserved as a specimen for scientific purposes. The poisonous species named above ought, whenever found, to be killed and preserved for scientific collections. If the boys of the country are to be allowed to shoot all the birds and stone to death all the reptiles, we may yet be compelled to surrender to the vermin.

In order to study the reptiles and amphibians of our State advantageously, the student ought to have some means of determining, first of all, the species he meets with. To this end I recommed Prof. Jordan's "Manual of the Vertebrates," which contains descriptions likewise of our mammals, birds and fishes. Then the student ought to begin observations on the liabits of such reptiles as he meets with, and to keep accurate notes of these observations. Among other things, he should note the kinds of localities each inhabits; when it appears in the spring, disappears in the fall, how it passes the winter; what it eats, and how it gets it and how it eats it; when, where and how it lays its eggs; how many, how large, and when they hatch; what the young look like, what changes they pass through, what they cat, and how they are cared for by the parent; what enemies the auimal has, and how it defends itself; what sounds it utters and the purpose of these sounds; what means are employed to bring the sexes together, and the time and manner of courtship. If anyone will tell us all these things, and such others as may be observed in the case of any one amphibian or reptile in Indiana, he will be certain to tell Rcientific men something that they do not yet know. But what is told, must be that which has been seen, and not what has been imagined.

Specimens should be preserved in alcohol. They may at first be placed for a few days in rather weak alcohol, some that has been used once. Afterward they should be submerged in strong alcohol; the strongest will keep them best. Bottles containing specimens should be closel tightly. Fruit-jars with rubber bands are excellent for almost everything. Above all things, have each specimen labeled with the locality wherc it was captured. Other interesting facts may be put on the label or be recorded in a note-book. Turtles are usually too large to enter ordinary jars. The shells may be cleaned and dried, or the whole turtle may be dried after extracting the entrails through a hole in one side. If, after drying, the whole body is painted with turpentine in which a little rosin has been dissolved, no insects will attack it. The specimen may not be a specially handsome one, but it can at lcast be identified, and this is the main thing.

It seems desirable that we should at as early a day as possible discover what species of amphibians and reptiles are found in our State, and what we can of 
their habits. To that end the writer invites the presentation or loan of specimens, and the communication of interesting observations; and for all such favors due credit will be given.

In order to facilitate the study and description of animals, zoologists have found it necessary to classify them; and they liave therefore arranged them according to their resemblances into various groups, known as classes, orders, families, genera and species. Animals that we recognize as being of the same kinds, we say are of the same species. Thus the copperheads all belong to one species, the banded rattlesnakes to another. Species that are much alike belong to the same genus. The several kinds of frogs belong to the genus Rana. The copperheads and the rattlesnakes belong to different genera, being distinguished by the presence or absence of the rattle. Families, orders and classes are successively ligher groups.

The Auphibians are such animals as the newts, salamanders, toads and frogs; and they form a CLASS distinct from the class of REPTILES, under which are arranged the snakes, lizards and turtles. The amphibians are most closely allied to the fishes; the reptiles to the birds, though differing so greatly in outward form. Amphibians usually lay their eggs in the water; their young are, with few exceptions, water-breathing tadpoles; the skin never is developed into overlapping scales or into plates, but is smooth and usually moist. Reptiles, on the contrary, breathe air by means of lungs at all times of life, never lay their eggs in the water, and have the skin formed into scales like those of snakes, or plates like those of turtles. Some of our salamanders resemble in form the lizards, but may readily be distinguished from them by having a smooth instead of a scaly skiu.

\section{THE AMPHIBIA.}

Our amphibians are divided into two orders, the UrodelA and the ANurA. The Urodela possess well-developed tails at all periods of life; the Anura have tails while in the tadpole stage, but when adults are tailless. To the Urodela belong the mud-puppies, newts and salamandere; to the Anura belong the treetoads, toads and the frogs.

The lowest urodele that is found in our State is the siren (Siren lacertina), a very strange and interesting creature. It lives in the Ohio and Lower Wabash rivers, but it will probably yet be found further north. It grows to a length of three feet, although it is usually smaller. Its body is slender, its tail long, the fore legs are present, but weak, while the hind ones are entirely absent. There are large, external gills, and the upper and lower jaws are furnished with a horny covering. Little is kuown about its liabits. In the large streams of probably the whole state there lives another somewhat similar animal, the mudpuppy, or water dog (Necturus maculatus). It has, lowever, both fore and lind limbs, and both jaws are well armed with teeth. Its gills are external, large and bushy. It uses its large flat tail in swimming. It appears to be nocturnal in its habits, and to eat worms and insects. Doubtless it will be found to eat many other small aquatic animals. It may reach a length of two feet, and is of a reddish color, with darker spots. Very often along the Ohio River fishermen catch on their hooks anotler large amphibian, the "hellbender" (Cryptobranchus alleghaniensis). It is a creature of a coarse and disgusting appearance, and may well inspire fear in persons not acquainted with it. It is, however, not poisonous, nor could it probably produce much pain even if it should bite one. It lias no gills, but there is on each side of the neck a small opening into the throat. Its head is flat, its mouth large, and its tail broad and coinpressed. Its color is nearly black, and its skin much wrinkled. It may 
occur from a foot to two feet in length. It is said to lay its eggs in August and September. It would be interesting to procure its tadpoles before the gills have been absorbed.

Next above these exclusively aquatic animals come the members of the family known as the Amblystomida. They greatly resemble lizards and are often called such; but they differ from the true lizards, as has been already stated, in having a smooth, moist skin instead of a covering of scales. They are also quite sluggish in their motions, while lizards are very active. These amblystomes may be distinguished from other families by having a row of teeth running across, and no band running lengthwise, the roof of the mouth. Often when these aninals are irritated the skin will emit a milky fluid, which may be disagreeable to some of their enemies. They are all entirely harmless and probably can not be made to bite, and if they did their feeble tceth could do no liarnı. Nevertheless many people greatly fear them. They are frequently found in cellars, open wells, under boards and logs, and in the mud and water of ponds. They all doubtless live principally on insects and worms. Many, but not all of them, appcar to pass the winter in ponds. During the summer they appear to burrow in the soil or hide away in damp places. Early in the spring they lay their eggs in the water in small bunches. The tadpoles are slenderer than those of frogs. We have in Indiana at least six species which have until now been all included under the genus Amblystoma. The small-mouthed salamander ( $A$. microstomum, Fig. 4,) is of a deep brown or black color, with a few minute grayish patehes and markings. There are 14 costal grooves running down the sides between the fore and the hind legs. Its body is long compared with that of the other species, the distance from its snout to the armpit being contained in the distance fron the armpit to the groin about twice. Jefferson's salamander (A. jeffersomianum) resembles somewliat the last, but has a shorter body, a broader head and a larger mouth. Its fingers and toes are long and slender, and it has 12 costal grooves. Its usual color is from ash to nearly black, with or without bluish blotches. Besides the typical form described above we may look for two varieties. One of these, fuscum, was originally described frow Hanover. It differs in being of a dark brown color and has an especially dark band along the sides. The other variety, called platineum, has been found in Ohio and Illinois. It is distinguished by being of a leaden color, with uumerous indistinct whitisl blotches.

The tiger salamander (A.tigrinum, Fig. 7, ) is our largest species of salamander, and is easily distinguished by its numerous bright yellow spots on the back and sides. There are 12 costal grooves. Many individuals of this species spend the winter in ponds. Their eggs are laid early in March. The tadpoles may become 3 or 4 inches long before losing their gills. The spotted salamander (A.punctatum) resembles the tlger salamander, but its yellow spots are in a row on each side of the back and there are none along the sides; costal groves usually 11 . It is not uncommon. The marbled salamander (A. opacum, Fig. 6 ,) is a short-bodied species, dark in color, with several silvery gray bands running across its back. It does not get to be so large as the species mentioned above, not exceeding, perhaps, 4 inchcs. lt probably occurs throughout the State, but is rccorded only from the southwestern portion. This species has been said to lay in tunnels under dead leaves its eggs to the number of 100 or more, and there to incubate them, both male and female curling up over them. When hatched the young betake themselves to the water. These observations are doubtless erroneous.

The short-bodied, or Cope's, salamander (A. copeanum) is known from a single specimen that was found near Indianapolis. It is of a dark color above, yellowish below. The distance from the snout to the armpit equals the distance from the 
armpit to the groin; (ostal grooves. 11 ; head, broad; tail, flattened; habits, unknown.

In the family of Salanandride the form is still lizard-like. The members of this group are to be distinguished from the Amblystomidae by having a single or double band of teeth rmoning lengthwise along the roof of the month. These may readily be detected by scraping gently in the roof of the mouth with the head of a pin. In front of this band there is nsually also a row of teeth rumning across the roof just inside the internal nostrils. There are, of course, aleo treeth on both upper and lower jaws. In the genus Sperlerpes the tongue is small and stands on a slender stalk like a little musliroom. The tongue may be thrust ont of the montl for a considerable distance, no doubt for the purpose of capturing their prey. (ireen's triton (Spelerpes bilineatus) has been found only in the sonthern part of the State. Its color is yellowish along the back and on the belly, while there is on each side a band of brown. There may also be a very narrow brown band along the middle of the back. The tail is abont one half the total length. It lives under stones and the like, usually not far away from the water. Its length is about three inches.

Baird's triton (S. guttolineatus) has not yet been found in the State, but is known to occur as far west as Central ()hio. It resembles Green's triton, bint has three distinct bands, the dorsal band broad, and its tail is considerably more than one-half the whole length. Its size is also greater, becoming six inches. The longtailed triton ( S. Longicaudus, Fig. 3, ) is wholly aquatic, living especially in the strcams of caves. It has been found at a few points in Southern Indiana, but will doubtless be discovered wherever there are rocky streams. It is our most beautiful species. The color is a lemon yellow, while scattered over the back and sides, and on the limbs and tail are numerous black spots. The tail is flattened and unuch longer than the rest of the body. The rel triton ( $S$. ruber) has not becn recorded from Indiana, but is found in both Ohio and Illinois. It is of a bright red color and ornamented with nunierous small black spots. It is found in marshes and along blallow streams, apparently leaving the water at night; length, about five inches. The purple salamander (Gyrinophilus porphyriticus) is common in Pennsylvania, and lias been found as far west as Central Ohio. It is, therefore, among our possibilities. The color above is grayish or purplish; below, white. The sides are of a salmon color or yellow. Th, re are no spots. The head is large and flat. It may become nearly six inches long. It is said to live in still water or on the land under loge and stones. It snaps fitrcely when disturbed, but is harmless. It eats insects.

'The Plethodons have a Hroal band of teeth running along the roof of the mouth. The tongue is large and attached by a narrow inedian band, leaving a broad free margin at each side and behind but none in front. The red-backed salamander (Plethodun erythronotus, Fig. '2,) is small, usilally attaining a size of three or fonr inches. It is said never to enter the water, but to hide under stones in moist places. Its young do not pass through the tadpole stage, but early lose their rudimentary gills. It would appear that the parents care for their young. The adults are of an ashy color along the sides, paler below. Along the back there is usually a broad red or cream-colored stripe from the head to the tip of the tail. This dorsal stripe is sometimes missing, in which case we have the variety cincreus. Costal grooves, 16 to 19. This species and its variety just named have been found in Southern Indiana. The slimy salamander ( $P$. glutinosus, Fig. 5,) has recently been taken near Bloomington, Monroe County. It is much larger than the preceding speciea, and is of a black color, with numerous small white spots. The tail is round, and there are 14 costal grooves. It hides under logs and in similar places, but lays its eggs 
in the water. 'The scaly salamander (Hemidactylium scutatum) is a rare animal, but it has been reported from Franklin County. It should be looked for all over the State. It may be known from any of our other salananders by having but four toes on its hinder feet. It is to be found, under $\operatorname{logs}$ in open woods, and is of a brown color above and paler below, with black spots on the sides and belly. It is said to be very active in its movements.

The brown triton (Desmngnathus fuscus, Figs. 1, 1a,) is supposed to live wholly in the water, hiding under the stones of shallow brooks. It is brownish or ashy above, often with nottlings of pink; below, pale, marbled with brown. Its teeth are arranged much as they are in the Plethodons. Tail compressed from near the base to the pointed extrenity. It has been said to lay its eggs in a string, which one of the scxes winds around its body. This curious habit needs confirmation, and it should be determined which of the sexes, if either, thus takes charge of the fillet of eggs. The eared triton ( $D$. fuscus auriculatus) is merely a variety of the preceding, distinguished by having a reddish spot below and behind the eye, and ninute spots of red over the body. It has been taken at Cincinnąti, $O$. The black triton $(D$. nigra) is another species that we may yet claim for Indiana. It belongs cspecially to the Sonthern States, but has been sent to the National Museum from about Chicago. It is uniform black, costal folds 12. "The "triton" (D. ochrophous) closely resembles the brown triton described ahove. It is of a brownish-yellow above, sides with a dusky band, belly palc without mottlings of brown. The male has no teeth on the posterior half of the lower jaw. It is aaid to live, partly at least, under stones away from the water. It is not known to necur in the State.

The green triton, or new $t$, (Diemyctylus viridescens, Figs. 8, 8a, ) has been taken only in the southern half of the State, but doubtless occurs everywhere. It is a beautiful and interesting little animal, of a greenish color, ank-nmamented with numerous red spots, which are surrounded by a ring of black. Its tail is broad and fitted for swimming. It lives in quiet pools, and grows to be three inches or more long. A variety of this species, called miniatus, lives under stones away from the water. It is red instead of green, bnt has similar spots. I have no record of its occurrence in Indiana, but it has been found at Cincinnati and near Chicago.

We are now to consider the tailless amphibians (ANURA). The frogs and toads are all voracions eaters of insects and wholly harmless, and should, therefore, receive the protection of every farmer and gardener. The first to be noted is the common tree-frog (Hyla versicolor). Its loud voice, heard especially in damp weather, its changeable colors, and its ability to creep up perpendicular surfaces by means of the disks on its fingers and toes, are its most striking characteristics. It resorts to ponds in the spring, sometimes in great numbers, for the purpose of laying its eggs. Pickering's tree-frog (Hyla pickeringi) is a much rarer animal, and, so far as I know, has not been found in Indiana, except near Bloomington. It is smaller than the common tree-frog, is white bclow, fawn color above, with a dusky $\mathrm{X}$ across its back. It should be looked for. The cricket frog (Acris giy.llus, variety crepitans) is a little species that lives along most of our streams. It has on its toes and fingers small disks and is hence called a "tree-frog," althongh it does not climb. When pürsued it springs into the water, but hastens to get out again. Its voice is shrill and noisy. Its body is ahout one incl long is of a brownish color above with more or less green, and pale below. There is some white about the lips. The typisal form, gryllus, may yet be found with us. It is distingushed by being stenderer and having a longer head. When the hind leg is laid along the side, the joint between the leg and foot rcach to the snout or beyond. Another "tree-frog" (Chorophilus triseriatus, Fig. 9,) occurs occasionally within our territory, though I know of but a single specimen having been found. lts digital 
disks are small and there is little or no webbiug on either fingers or toes. Its body is but an inch long and slender. Its color is ash, with from three to five longitudinal dusky stripes on its back.

The American toad (Bufo lentiginosus) is well-known. Cruel boys ought to be taught to respect it, because its appetite for insects can scarcely be satisfied. The toad's full-grown tadpoles are much smaller than those of frogs. The genus Rana includes all our other frogs. Our common large spotted frog is known as the leopard frog ( $R$ halecina). Its spots are surrounded by a ring of pale color. A variety of the species having spots without the pale ring should be looked for in Indiana. Another frog closely related to the leopard frog is known as Rana areolata; and a frog found in Benton County has, by Prof. Cope, been assigned to it as a variety called circulosu. Its size is medium. The head is larger than that of the leopard frog, and the spots smaller and more numerous. The males are stated to have vocal sacs opening externally behind each angle of the mouth. Additional specimens should be sought. The marsh, or pickerel, frog ( $R$. palustris) is also much like the leopard frog, but is smaller, and has on it back four rows of squarish spots. The male has two internal rocal sacs. It is said to occur in Indiana, but I have not obtained it. The green frog ( $R$. clamata) is one of our largest frogs, and is found probably in all our streams. Its spots are not so distinct as in the species named above. It is much like the bull frog ( $R$. catesbiana), but differs especially in having, along each side of the back, an elevated fold of the skin. The bull frog does not have this fold. The latter species is our largest frog, sometimes attaining a total length of eighteen inches. Its loud, sonorous voice is well-known. Its tadpoles attain a large size before transforming, and must pass at least one winter in ponds. This species is the one usually eaten. The wood frog ( $R$. sylvatica) is a beautiful species, not so large as the leopard frog. Its color is a silvery gray, with of ten a tinge of pink. It may be readily known from other species by a dusky band on each side of the head, running from the snout to the ear. It lives in damp woods, hiding about logs and in leaves; but if near the water when pursued, it betakes itself thither and hides alongside of stones, from which it 1 distinguished with difficulty. It is morlerately common.

\section{REPTIL KS.}

These, as already said, liave the skin furnished with overlapping seales like those of snakes, or with large, thin plates, as in the case of turtles. 'The soft-shelled turtles form the only exception.

The snakes form an order (OrindiA), and we liave in Indiana about thirtyfive species. Of these, all except the three or four already mentioned are nonvenomous. Several species are small in size, feeble of body, and of mild disposition The larger species are strong, active, and given to exercising their natural right of defencling themselves. When irritated or suddenly attacked, some of them may strike fiercely, and in so doing may cause injury in two ways. By means of their short, sharp teeth they may scratch the skin a little and even draw blood, and they may give the aggressor a sudden and tremendous fright. This last is the most serious part of the affair.

Snakes possess many curious and interesting habits, and there is no doubt that much remains to be learned concerning them. The food they eat depends somewhat on the size of the snake; but it consists usually of living animals. Sometimes, however, they will eat things which they liave found dead-"cold victuals." They are ready to eat one another. Their means of capturing their food varies. It would be interesting to know just how a house snake can capture a living rat 
and swallow it. Some lay their eggs in the earth, while others bring forth their young alivc. Do those which lay eggs guard them and care for the young? It appears so, in some cases. The fcmales of many spccies afford the young a refuge from danger by permitting them to pass down the maternal throat. Well authenticated cascs of this are yet desirable.

The principal characters here used in distinguishing our snakes are found in the number of the largc plates covering the belly, ventral scutes, counting fron the liead to the vent; the structure of the anal plate, the ventral seute just in front of the vent, which is sometimes entire, sometimes divided by an oblique cut; the number of rows of small scales counting from one side over the back to the other side; the smooth or keeled condition of the scales; and the coloration. The garter snakes are examples of snakes that have keeled scales and an entire anal plate; the watcr snake and racers of those that have divided anal plates.

The worm snakes furuish us with two species, known as the ground-snake (Carphophis amonus) and Helen's snake (C. helence, Fig. 13). They arc small, rather flattened suakes, with small heads. Their color is a rich chestnut brown above and red or pink below. They have thirteen rows of smooth scales and a divided anal plate. They are harmless, and live among dead leaves and in soft earth. So far they have been found only in the southern half of the State. The gen us Virginia contains two species of small, plainly colored snakes, known as "brown snakes." They hàve smooth scales, in fiftcen or scventeen rows, a divided anal plate, and are grayish brown above and reddish or yellow below. Kenuicott's brown snake ( $V$. elegans) has been found in Brown County. It las seventcen rows of seales. Valcria's snake ( $V$. valerio $)$ has but fifteen rows of scales. It lives in the Southern States, but may be looked for in Indian:t. The striated brown snake (Haldea striatula) closely resembles Virginia elegans, but has keeled scales. It is redolish gray above and more or less red beneatl. It is not yet knowu in Indiana.

The red-bcllied horn snake (Farancia abacura) has becu found only in Knox County. Seales smooth, in mineteen rows, and anal plate divitled. The color is a bluish black above, while below there are square spots of red and black. On each side there is a series of nearly squarc red spots. "The horn, or "loop" snake (Abastor erythrogrammus) differs from the preceding in having three red lines along the sides. It has beeu found in Southern Illinois, and should be sought for in Sonthern Indiana. It is not the "hoop snake" of the newspapers. The scarlet suake (Cemophora coccinea) is another Southern snake, but it has been sent to the National Museum from Ohio. Its color is a bright scarlet, broken by about tweuty double rings of black, inclosing cach a yellow one. Its scales are smooth, in nineteen rows, and the anal plate is divided. The head is small and pointed. This will be a rarity for the fincler. In the genus Ophiholus, to which belong several of our larger snakes, the scales are smooth, in twcnty-one or more rows, and the anal plate is entire. The scarlet king snake (O.doliatus, var. doliatus, ) is rare in the State, but does occur in the sonthern portion. It is red, with twenty or morc pairs of black rings, each pair inclosing a yellow ring It thus resembles the scarlet snake described above, but differs in having twenty-one rows of scalcs and an entire anal plate. 'The milk, or honse, snake ( $O$. doliatus, var. triangulus, ) is very common everywhere. It differs wholly from the preceding variety in its coloration, but agrees with it in other respects. Its ground color is gray, and there are three series of brown spots above. It devours mice and sometimes rats, and for this reasou, probably, it is sometimes found about houses. Most people, however, wuuld prefer that it should not make itself too familiar. The femalc appears to lay her eggs in a nest, which she guards, and to rescue her young from danger by letting them pass down her throat. The king snake $(O$. getulus) is also found in Southern In- 
diana. It has twenty-one rows of scales; the color is black, and across the back there run about thirty narrow yellow lines which fork on the sides. In the Southern States this snake is liglily regarded and protected on account of the warfare it makes on rattlesnakes. By suddenly springing upon and encircling the rattlesnake witl its coils, the king snake sool squeezes the venomous reptile to death. Then, commencing at the head, the victor swallows the rattler whole. It treats other snakes in the same fashion. In the variety called sayi, the yellow transverse lines are broken up into dots, and nearly every scale may have a white dot. It has been found at Mt. Carmel, Ill., on the Wabash River. Still another variety called niger has been found in Knox County. It is entirely black. It may be known from the comnion black snake by having twenty-one rows of scales instear of seventeen. Evan's king snake ( $O$. calligaster) has been found at Mt. Carmel, Ill., and doubtless will yet be taken in Indiana. Its smootll scales are in twenty-five rows, and it has cliestnut-colored blotches along tle back and sualler spots along the sides.

The ring-necked suake (Diadophis punctatus) is one of our smallest and most beautiful serpents. It may be readily distinguished from any other of our species by its coloration, being-blue black above, yellowish beneath, and having a white or yellow ring around the neck. There is sometimes a row of black dots along the middle of the bclly. The variety amabilis will doubtless also be found within our limits. It may be know from the other form by having its belly thickly covered with black dots.

We have in Indiana two species of green-snakcs, both of which are slender, graceful aninals of a bright grcen color. The smooth green-snake (Cyclophis vernalis) lias smooth scales in 15 rows. It will be found throughout the State. Its eggs, hid about under bark, etc., liatch probably during August. The young are about 5 inclies long. The keeled green snake (Phyllophilophis cestivus) may be known from the preceding by liaving keeled scales in 17 rows. It is southern in its range, but has been found at Now Harmony and in Dearborn County.

The genus Coluber contains some of our largest and most active snakes. They are known as "Racers" and "Pilot Snakes." They may all be known by liaving keelerl scales in fron 25 to 29 rows, the keels often wanting on the outer rows, a divided anal plate, and from 200 to 235 ventral scutes. They are all doubtless very efficient in keeping down the numbers of vermin of various kinds, although they are equally ready to devour young birds. Emory's racer ( $C$. emoryi) belongs es. pecially to the States southwest of us, but it is said to have been taken at Mt. Carmel, IIl., and in Franklin County, Ind. The scales are in 29 rows, only 6 or 8 rows on the back keeled, and there are 210 or more ventral scutes. The general color is aslı gray, witl many brown blotches: The fox snake (C. vulpinus) lias 25 rows of scales, from 200 to 210 ventral scutes, and many chocolate colored spots across the back. It probibly occurs throughout the State. The pilot snake, or black racer (C. obsoletus), lias 27 rows of scales and 230 or more ventral scutes. The color above is lustrous black, some of the scales with white erlges; below, slate black, with some white about the throat and chin. The common black suake has but 17 or 19 rows of scales, and the black variety of the king snake but 21 rows, and the scales of both the latter are smooth. The black racer lias been found in Knox and Franklin counties. It is said to be much given to climbing trees to get young birds. The young are said to run down the motler's throat for safety. This snake may reacli a length of 6 feet. The spotted racer (C. guttatus) has also been found in Franklin County, Ind., and Mt. Carmel, Ill. Its scales are in 27 rows, its ventral scutes 210 to 235 . It is a reddish snake, with many brick red blotclies along the back. 
The bull, or pine, snakes belong to the genns Pityophis. They grow to be large snakes, have the keeled scales in from 29 to 37 rows, the ventral scutes from 200 to 240 in number, and the anal plate entire. Whether or not any of the species live in Indiana is not ccrtainly ascertained, but it is quite probable that at least one does. The pinc snake ( $P$. melanolencus) probably does not come so far west, and yet it has been found in Ohio. It, as well as the next specics, bas a liabit of puffing and hissing and even of making a low roaring sonnd, whence its name. Holbrook mentions one 9 feet long. It is white, with chestnut brown blotehes, scales in 29 rows, and abont 225 ventral plates. The Western pine snake, or bull snake ( $P$. sayi), is also much spotted. Scales usnally in 25 rows and about 225 scutes. It is Western in its distribntion, but has been found at several points along Eastern Illinois, and will donbtless be found with in our borders. The black snake (Bascanium constrictor) is well-known everywhere. The "blue racer" is a variety, or stage of growth, of the same species. The very young is much different from the adult. The scales are smooth, in 17 (or 19) rows, the anal plate bifid, and there are 170 or more ventral scutes. They climb trees and ravage birds' nests and probably destroy rats and mice. They are accused of stealing eggs and milk from milk houses, but that they suck cows, as has been said, is highly improbable. The rasping of thcir tceth on the cow's teats would hardly contribute to the tranquility of the rural scenery. They will, no donbt, sometimes squeeze human beings a little, as their name indicates, but nsually they are only too glad to escape. In such a case relief may be sought by unwrapping the tail.

The striped, or garter, snakes are well-known to everybody. They arc perfectly harmless, although they may strike spitcfully. The genus Eutonia may be recognized by the keeled scales in 19 to 21 rows, the entire anal plate, and the longitudinal stripes. The ribbon snake, or swift garter snake (E. saurita), is very long and slender, the tail forming fully one-third the total length. The color is brown, with three yellowish stripes. This is onc of the snakes that is reputed to "swallow its young." It has been said that they sometimes prodnce as many as 30 young at oncc. Fairie's garter snake ( $E$. faircyi) closely resembles the preceding, of which it may he only a variety. Its ground color is almost black, and its tail is usnally a little less than one-third of the total length. The Racine garter snake ( $\boldsymbol{E}$. radix) is probably rare in the State, but it has been found. It inay be known from our other garter snakes by having the stripe along the sides on the second and third rows of scales instead of the third and fourth. Its ground color is also darker than usual in the rest. Its tail forms but about one-fifth the tolal length. The garter snake ( $E$. sirtulis) is onr commoncst snake. It has a tail only about one-fifth the total length. They sometimes collect together in great numbers to hibernate. They produce an almost incredible number of young. The young are so far dereloped when the eggs are laid, that they soon hatch. Mr. F. W. l'utnain states that he found 42 nearly-developed young in one snake 35 inches long. Mr. E. S. Thrall, of New Harmony, who has had much experience with snakes, tells me that he has in alcohol 64 young ones that left the mouth of their mother after sle was killed, and several others escaped. ()f this species we have several varieties. One, purietulis, has more or less bright red between the spots along the sides. Another, ordinata, has the stripes indistinct.

The genus Storeria includes two staall harmless snakes that will probably be found throughout the Statc. They may be known by their kesled scales in 15 or 17 rows, their dirided anal plate, and ycllowish-brown color. Storer's brown snake (Storeria occipitomaculata) has a pale band along the back, sometines indistinct, and some ininute dots. The belly is yellow or red. There are three pale spots on the back of the head; scales in 15 rows. Dekay's brown snake ( $S$. dekayi) is 
apparently more common in Indiana than the last. It has also a pate dorsal band and is grayish below. It has 17 rows of scales. Its characters are closely those of the striated brown snake (Haldea striatula) already described. The latter is, however, without any indications of stripes. Kirtland's snake (Tropidoclonium kirtlandi) has rcales and anal plate like the two preceding species, but the seales are disposed in 19 rows and the snake is spotted with black. Its belly is usually salmon-red. It is quite comnon about Indianapolis. The lined snake ( $T$. lineatum) has not yet been found in Indiana. It is southern in its distribution but has been reported from Ohio; consequently we may expect it in Indiana. The scales are keeled, in 17 rows, the anal plate entire. (olor, grayislr-brown with a light line along the back. Belly pale, with two rows of black spots.

Of the water snakes we have in Indiana some five or six speeics. The genus to which they belong is known as Tropidonotus. The scales are keeled and are arranged in from 19 to as high as 33 rows, and the anal plate is divided. When there are 19 or 21 rows of scales the coloration consists of five or inore dark bands running lengthwise and lying on a lighter ground. When there is a greater number of rows of scales, the darker colors are disposed in spots and blotches, or the eolor may be almost uniform brown or black. The species are all aquatic and sone of them attain a large size. The water suake ( $T$. sipedon), sometimes called the "water moccasin," Lut quite a different thing from the venomons water moccasin of the Southern States, is our commonest species, and way be scen swimming in the waters or hiding among the stones of any of our streams. It is not poisonous, but a large one, if caught, might make a lively fight. They produce a large number of young and many persons have observed them, when alarmed, seck a safe retreat down the throat of the mother. The seales are in 23 (rarely 25 ) rows and the body is variously spotted and cross-banded with brown margined with black. Specimens are sometimes found that are quite uniform brown or black. Woodhouse's water snake ( $T$. sipedon var. wnodhouseii), a variety of the common. water snake, belongs to the Southwest, but has been found at St. Louis and about Chicago. We may, therefore, seek for it here. Its scales are in 25 rows and there is a row of black blotches, about 40 in number, along the middle of the back and another similar row on cach side. Another variety of sipedon, called erythrogaster, is of a dull black above, the belly dull yellow or copper color. It has been found at Mt. Carmel, and, being a water snake, it can hardly be excluded from forming a part of our fauna. Holbrook's water snake ('T. rhombifer) has the scales in 27 rows and is light brown with three series, a dorsal and two lateral, of lark, squarish blotelies. Mr. Robert Ridgway, of the National Museum, found this snake to be excessively abundant at Wheatland, Knox County. The banded water snake ( $T$. fnsciatus) resentbles 'T'. sipedon. Scales in 23 or 25 rows. (irnund color brown to black, with a series of black blotches along the baek and aboit 30 triangular or oblong spots of red along each side. Belly reddish white. This species has been found in Knox County by Mr. Ridgway. Another water snake (T. cyclopium) has been fumul in Florida and Southern Illinois, and may, therefore, extend its range into Indiana. Its scales are in from 27 to 33 rows. There is a row of little scales lying between the lower border of the eye and the large scales covering the upper lip, an unusual thing. Color above brown, with many narrow, sometines indistinct, dark bands running up the sides and meeting or alternating above. Abdomen yellow anteriorly, brown behind; more or less spotted. Liraham's queen snake (T. grahamii) has not been found in the State, but since it extends from Michigan to Louisiana, we unay confidently look for it. The scales are in 19 or 21 rows and there are about 160 ventral scutes. The ground color is brown, and there is, along the back, a broad band of yellow, and another on each side. Each of these bands 
is margined with black. 'The brown queen snake, or leather snake ( $T$. leberis), has been found in Franklin and Parke counties and may, therefore, be sought for throughout the State. Scales in 19 rows. There is, on each side, a ycllow band; on the back three narrow black stripes, and four dusky bands on the belly. One of these snakes, in the London Zoölogical Gardens, produced, in August, five young and scveral eggs at the same time.

The hog-nosed snakes are very peculiar in many respects, and are very abundant in some parts of the State. They are serpents with a heavy body and large head. They have the power of flattening the head and boly and thus slowing their displeasure. The scales are keeled and in from 23 to 27 rows, and the anal plate is divided. 'They may be known from all others of onr snakes by having the snout brought to an edge along the sides and to a point in front, and then turned up somewhat, so as to resemble a pointed dirt shorel. When attacked, these snakes make very threatening movements, flatten themselves and sometimes hiss violently, as if they were very dangerous. They are so regarded by many peoplc, and the bite of these "spreading adders" is as much feared as that of the rattlesnake. On the other hand, herpetologists and people who have collccted these snakes pronounce them perfectly harmless. Some of their back teeth are much larger than the others, and look like fangs, but they have no connection with poison glands. It is barely possible that the saliva lias poisonous qualities. But, while they make violent threats, it is said that they never even strike. When persons have been snake-bitten, the suake ought always, if possiblc, to be preserved for identification. The hog-nosed snake, blowing viper, or spreading adder $(H$. platyrhinus), is likely to be found anywhere, perhaps, in the State, but is most abundant in the southern portion. It is of a yellowish brown color with a number of dark blotches along the back and spots along the side. Scalcs in 25 rows. To illustrate the stories that have been told of this snake, I quote the following, taken by Miss Hopley from an old writer: "When approached, it becomes flat, appoars of different colors and opens its mouth, hissing. Great caution is necessary not to enter the atmosphere which surrounds it. It decomposes the air, which, imprudeutly inhaled, induces langnor. The person wastes away, the lungs are affected, and in the course of four months he dies of consumption." This snake has been said also to "swallow the young." Morc obscrvations are needed on its habits. A variety of this species, the black viper, niger, differs in being of a uniform black above, slate color below. It is common in some localities, perhaps more common than the spotted variety. The sand viper $(H$. simus, Figs. 14, 14a) resembles the spotted variety of the preceding species. It is to be distiuguished from it by an examination of the upper surface of the head just behind the snout. In both species the sharp-edged plate that eovers the snout has, just behind it, in the middle line, another quite small plate, and at the sides of, and behind the latter, other quite large platcs. In $H$. platyrhinus this little median plate comes into direct contact with the large platcs; in $H$. simus, it is surrounded by five or more little scales, which thus separate it from the larger plates. The sand viper is apparently not common in the State.

By far the most interesting of all our reptiles are the rattlesnakes and copperheads, and this is true principally because of the dangerous naturc of their bites. In these snakes the maxillary bone has in it but a single functional tooth, and this is developed into a large fang. This fang has in it a canal which begins near the base of the tooth and opens near the tip, in front. The duct of the poison gland is connected with the upper end of the caual, so that when the snake strikes, the poison is injected through the tooth into the wound. Under ordinary circumstances the fang lies against the roof of the mouth, with the tip backward and en- 
tirely concealed by a loose sheath of mucous membrane. When the snake delivers its blow, the bone carrying the fang is rotated in such a manner as to erect the fang and make it point downward and forward. The poison is chemically and physically much like the white of egg. Its virulence is not destroyed by drying, freezing, boiling, or treatment with alcohol. It appears tliat no chemical reagent will neutralize it which will not at the same time destroy the tissues of the body. When thrown into the blood in proper quantity, it causes great nervous prostration, interferes witl the action of the heart, and produces something akin to blood.poisoning. The remedies for snake bites are, sucking out the poison, excising immediately the wounded portion, and the drinking of considerable quantities of alcoholic liquors. Alcohol acts, not as a chemical antidote, but as a powerful stimulant, which enables the system to resist the depressing effects of the poison. Large quantities of whisky or brandy are sometimes needed to accomplish this result, but not enough ought to be taken to produce stupefaction, since then the alcohol will lend its aid to the deadly poison.

Of the rattlesnakes we have probably no more than two species. Of these, the banded, or timber rattlesiake (Crotalus horridus, Fig. 16), is the largest, most powerful and most dangerous. It is, liappily, becoming far less abundant than it formerly was. Of course, every specimen of this snake that is found ought to be killerl, but killed in such a manner as to injure it as little as possible, and then it should be preserved for scientific purposes. The rattlesnakes have many enemies. Black snakes attack them successfully and either choke them to death or pull them in two; and they probably sometimes eat them. The king snake is known to kill and swallow the rattlesnake. Hogs devour them and are usually little injured by being bitten. This immunity from being poisoned is due to their thick layer of fat. When the hog is bitten in some part that is full of bloodvessels, it fares as badly as any other animal. Deer are said to destroy them by jumping on them and trampling them with their hoofs. But civilized man is their most implacable enemy, and before him they soon disappear. The banded rattlesnake may be distinguished by having the greater part of the upper surface of the head covered with small scales. The uassasauga, or prairie rattlesnake (Cuudisonu tergeminu, Fig. 15), is smaller than the preceding species, but sometimes reaches a length of three feet. It may be known from its liaving the upper surface of the head covered with a few large plates, instead of small scales. It has also, usually, about scven rows of spots on the back and sides. There is, however, a variety that is entirely black and without spots. The spotted, pale-colored variety appears to be found on open prairies; the black variety in swampy lands that are covered with brush and trees. This species appears to belong rather to the northern half of the State. Notices of its occurrencc south of Indianapolis are desired. Both the banded rattlesnake and the massasauga are known to afford, in their stomachs, a refuge to the young in time of danger.

The copperliead (Ancistrodon contortrix) is a well-known and widely-distributed snake, being found from Massachusetts to Texas. It may orcur in the northern half of Indiana, but I know of no records to that effect. In some portions of the southern part of the State it is only too comuon. Its broad, flattened head, its fangs, and its yellowish or chestnut color, will distinguish it sufficiently from any of our other snakes. There is at least one case on record of its having been swallowed by the black snake. It has been said that neither the rattlesnakes nor the copperheads are ever found about tobacco plants. This is an error, I think. Persons living in the tobacco-producing regions can give some information on this subject. The water inoccasin (Ancistrodon piscivorus) is a venomous serpent that lives abundantly in the streams of the Southern States. It occurs also in Southern 
Hlinois, and instances are reported of its being found in Southern Indiana. It resembles somewhat the water suake (Tropidonotus sipedon), whieh also is sometimes ealled "water moccasin," but its stouter body, broad, flat head, its fangs, and the white lines about the mouth will distinguish it. Dwellers along the Lower Wabash and Ohio rivers should be on the lookout for this snake, and when it is found report should be made, accompanied by the snake as final proof.

Of the order of Lizards, we have in Indiana probably not more than five species, and only three of these are known with certainty to occur. As has before been stated, the lizards are to be distingnished from the salamanders by the possession of scales like those of snakes. They are, besides, wholly terrestrial, while the salamanders are usually more or less addieted to the water. The brown-backed ground lizard (Oligosoma laterale) has hitherto been fonnd only at Wheatland, in Knox County. It is a slender lizard with very smonth seales and a tail about twice the lengtl of the body. Its general color above is bronzy-green, and there is on each side a dark stripe; below, white; tail, bluish. The blue-tailed lizard (Eumeces fasciatus) will probably be found throughout the State. It lives about stumps, old logs, and under the bark of dead trees. It is very active and dificult to eatch. The smaller specimens are of a blue-black color, with five yellow or whitish streaks running lengthwise the body, and the tail is bright blue. Older and larger specimens lose the stripes and the blue of the tail, more or less, and the general color becomes more faded, but of ten, also, more or less red. The head is likely to beeome quite red. Old specimens may become a foot or more in length. The six-lined lizard (Cnemidophorus sex-lineatus) is not known to have been found in the State, but sinee it oceurs in Conneetient, Maryland and in Western Illinois, well toward the north of that State, we ean scarcely doubt that it will yet be taken in Indiana. It is covered with small scales, is of a yellowish-green or brownish color, and has on each side of its body three or four stripes of ycllow. The abdomen is silvery. Search should be made for it. The alligator lizard (Sceloporus undulatus) has been found abundantly in Franklin County, and oceasionally in Monroe, but nowhere else, so far as I know. It niny be readily recognized. It is covered above with rather large keeled scales, which give it a rough appearanee, while below they are smoutl. Above, the color is brownish, with sonie irregular bands of black. The throat and sides are greenish-blue, or even indigo-blue. It is very active and lives in dry, sunny sitnations. It will probably be found in various localities in Southern lndiana. One of the most remarkable reptiles in our eountry is that known as the glass snake, or "joint snake" (Ophisaurus ventralis), although it is, after all, no snake at all, but a lizard. It is long, slender and snake-like in form and has no legs, but it differs from any of our snakes in having the belly covered with small scales instead of scutes. The tail portion of the body is very long, and, like that of other lizards, quite brittle; so that, when the animal is struck, it appears sometimes almost entirely to fly into piees. It is a common notion, where this animal nccurs, that these pieces will eome together again in the right order and the animal be in as good shape as ever, but of course this is absurd. P'rof. John Collett reports lıving seen this reptile some years ago in Warren County, and it has been taken at Mt. Carmel, Ill.; so that in all probability it may yet be found on the eastern side of the Wabash River. It should be looked for all along the western border of the State. It is sometimes yellow, sometimes dusky, always with black and yellow stripes running lengthwise on the back and sides. It is entirely harmless, and to kill it without the intention of preserving it is a piece of eruelty.

The order of Turtles is so well known that it does not need liere to be charaeterized. We have in Indiana about a dozen and a half species. Their habits 
vary a good dcal, but by far the greater part of them are aquatic and carninorous. In most turtles, both the upper portion of the shell (carapace) and the lower portion (plastron) are covered with large, thin plates which differ somewliat in form and number in the various families, and thus serve to characterize them. In the soft-slielled turtles, however, the cuticle is soft, and not modified into plates. The turtles are of economic importance, principally because of the excellent food furnished by the flesh of some species. They arc not utilized to the extent that is possible, and probably most of the species that attain a sufficient size inight be eaten. Of the soft-shelled turtles we have three species. They are entirely aquatic, seldom leaving the watcr exccpt for the purpose of depositing their eggs in the sand of the river shorcs. They are said by Agassiz to live principally on shell-bearing mollusks, but they will, no doubt, eat almost any small animal. Their labits need nore study. The leathery turtle (Amydu mutica) will probably be found in all the larger streams of the State, since it has been obtained at Madison and in the Wabash at Dclpli. This species nua be distinguished from the two following by the fact that the partition wall between the nostrils has no little ridge standing out from it on each side into the nasal passage. It has also a depression along the middlc of the back instead of a low ridge, and there are no spines on the front edge of the carapace. Dusky spots on the back, but none on the lower surface of the borly, neck and feet. The fierce soft-shelled turtle (Aspidomectes ferox) is on recorl only from Madison. It is common in the Southern States, but may be expected anywhere along the Ohio River. It may be known from the preceding species by the ridge projecting into eacl nasal passage from the nasal septum, and by the low ridge along the middle of thc back. When young, too, there are usually two dark lines, or two rows of black spots around the edge of the carapace. In the leathery turtle and in the next spccies named, there is only one such line; under surface of bolly, fcet and neck, white. This may be sought for as a rare species in our State. The spiny soft-slielled turtle (Aspidonectes spinifer) is common in all of our streams. It is one of the best of the turtles for fool. It has the ridges on the nasal septum, like the preceding species, but it differs from both the just-described species in having the lower surface of the feet and neck mottled with black. The snapping turtle (Chelydia serpentina) is too well known to everybody to require description. Both the eggs and the animal are often eaten, but the flesh may become musky in advanced age. It is a very strong, fierce and voracious animal, which lives principally on crustaceans, fishes and yonng ducks, but will also eat vegetable food. There is, living in our region, another turtle, related to the snapping turtle, but which grows to be mucli larger and stronger, and is much more fcrocious than the latter, and is also far rarer. This is the alligator snapping turtle (Macrochelys lacertina). Agassiz mentions one whose skull measured nine inclies between the eyes and which was estimated to weigh nore than 100 pounds. This interesting animal has bcen found most abundant in the streanis of the Southern States, but Mr. Harry Garman, of Champaign, IH., informs me that it has been taken in the Wabash a short distance below Mt. Carmel. It has also been reported from Wisconsin, and in the National Museum, at Washington, therc is a specimen from Northville, Mich. Persons living along the Iower Wabash ought to look for this turtle and, if possible, send specimens of it to some of the museums of the State. It differs from the common snapping turtle in having a larger head, which is covered with smooth, symmetrical plates; a more pointed snout; jaws unore looked; the carapace with threc prominent ridges, which do not disappear with agc, and the under surface of the tail witl many small, overlapping scales, in-tearl of two rows of large scales.

The musk turtle (Aromochelys odorata, Fig. 9) is apparently rare in the State, 
but yet likely to be found everywhere. It has been taken in Franklin County and at Mt. Carmel, Ill. It is onc of the snaller turtles, the shell not usually becoming more than about four inches long. It lives in quiet strcans and ponds and is quite active and ready to defend itself. It gives forth a strong odor. The head is large and strong, the snout much projecting beyond the lower jaw; the carapace is usually more or less kceled; the plastron with the anterior lobe movablc on a sort of hinge, the posterior lobe not inovable. The mud turtlc (Cinosternum pennsylecinicum, Fig. 12) is much like the preceding in size and general appearance, but differs in having the shell more rounderl above and without a keel, except when young; and the plastron has both the anterior and the posterior lobes movable on the middle portion, so that the animal can pretty effectually close its shell. The male has a curious claw at the tip of the tail. The mud turtle lives in the same situatious as the musk turtle, and is atso odoriferous. It is probably even rarer with us than the musk turtle. I have been told that it oecurs at Mt. Carmel, Ill. It may be expected to occur anywhere in the State.

In the genus Pseudemys are contained three species of onr turtles which are entirely aquatic and which attain to a considerable size. 'They are cliaracterized by the moderately depressed shell, the broadly wehbed fcet, the upper jaw with a small notch in front, and especially hy having just insicle the cutting-edge of both lower and upper jaws, a broad flat surface along which runs a distinct ridge. They have twelve plates on the plastron. The hieroglyphic turtle, or llolbrook's terrapin (P.hieroglyphica), appcars to be excecdingly rarc, but there is a specimen in the State Geologist's office that was scnt from Mt. Carmel, Ill. The shell is very flat, deeply scrrated behind and the head unusually small. 'The shell above is greenislibrown, with irregnlar yellow lines; below, dingy yellow. Troost's terrapin ( $P$. troostii) is also rather rare, bnt it lias becn obtained at Wheatland by Mr. Ridgway. The carapace is dark green, with yellow stripes running downward on the sides, and many spots. The plastron is yellow, with a large black blotcl on each of the twelve plates. There are several yellowisl stripes on the lower side of the neck; carapace somewhat notched behind. The elcgant terrapin ( $P$. elegans) appears to be quite common in the Lower Wabash. It is brown above, with yellow lines and spots, and the plastron is yellow with a dark blotch on each plate. It is especially characterized by the presence of a blood-red band on each side of the ncck. The map turtles have a flatter carapace than those just described, which flares ontward more, has a distinct keel along the back and is dceply notched behind. There is no notch in the upper jaw and the that surfacc inside the cutting-cdge of the jaws is not provided with a ridge. The map, or gengraphical turtlc (IFalacoclemmys geographica), is common everywhere in our rivers. The color is usually greenishbrown, with irregular and interlacing yellow lines. Plastron yellowish with some black. Many yellowish stripes on legs, tail and neck. The young are broadly rounded, with the carapace kecled and furnished nearly all around with shallow notches. The neck is striped and there is a spot behind each eye. Le Sueur's map turtle (M. lesueuri, Fig. 10, young) rescmbles the preceding but is grayer and has each of the plates along the back furnished with a black proccss which overlaps the plate next behind. The young have a very high keel with large processes on the plates, and the carapace is deeply notched behind and on the sides; so that, on the whole, they have rather a grotesque appcarance.

The "painted turtles" are the most beautifully colored and the most graecful that we have. They are much flattened, never at any time hare a trace of a dorsal keel, and have no ridge on the thattened, grinding surface of the jaws. The upper jaw is slightly notched in front, and on each side of this notch there projects downward a little process of the horny jaw, forming a tooth. The thrce rows of 
large plates of the carapace, the middle and the two lateral, are rather plain, but the little plates around the margin are beautifully colored with bright red, yellow and black stripes. Head, neck, feet and tail, spotted and striped with red and yellow. The plastron is sometimes bright yellow, sometimes orange. They live in quiet waters and are very shy. The painted turtle (Chrysemys picta) has the plates of the middle row of the carapace lying exactly between the corresponding plates of the lateral rows, so that that there are rows of plates running directly across the back. The margined painted turtle (Chrysemys marginuta) hats the middle row of plates alternating with those of the lateral rows. Both species are found in the State, probably in almost every locality. C. muryinula is, however, the most common form. It is desirable to learn to what extent $C$. picla is represented with us. The spotted turtle (Chelopus guttutus) is with us a very rare animal, having been found only a few times in the northern part of the State. It is a small turtle, the carapace reaching a length of five inches. In this species the fect are not so mucl webbed as in those previously mentioned, and they live less exclusivcly in the water. The carapace is withont a keel, while the plastron is broad and notched behind. It is wholly immovable on the carapace, and its parts are not movable on onc another. The upper jaw is notched in front and the lower jaw ends in a sharp point, directed upward. The carapace is black, with numerous yellow dots larger than pinheads. Top of the head black, with similar yellow dots. Blandings box tortoise (Emys meleagris) is also very rare, and is found in Northern Indiana. It seems, however, to live in fields, away from the water. Its upper jaw is broadly notched in front, and the lower jaw rises upward to a point. The plastron is capable of moving on the carapace, and it is itself divided by a transverse suture, so that the front and hincler parts can close up against the upper shell. It is jetblack above, with numerous yellow spots and blotches. The ycllow sometimes covers a considerable part of the surface, but is sometimes entirely lacking. Specimens of this species that may be secured are worthy of careful preservation.

The box turtle (Cistudo clausit) is wholly terrestrial in its habits, never going about the water. Indeed, it is said that they can not even endurc rail. Their feet are almost without a web, the carapace high and vaulted, and the plastron has a transverse hinge on which the front and hinder portions can move and thus completely close up the shell. The colors of this turtle vary a good deal. The ground color is black and this is varicgated with yellow in spots, bands and blotches, in smaller or grcater amounts. Sonetimes the yellow occupies the greater portion of the surface. The young always have a keel along the carapace, and traces of this often remain. This box turtle will probably be found sparingly all over the State, but in the southwestern portion it is quite common. The thrce-toed box-turtle ( $C$. clausa var. (riunguis), a variety of the species just named, is remarkable for liaving only three toes to its hinder feet. It bclongs to the Southern States, but lias been found as far north as St. Louis. It may, therefore, be looked for in Southern Indiana. The painted box tortoise (Cisludo ornata) is quite common in Kansas, but it has been found as far east as Wayne County, Illinois. It is thercfore to be looked for in Western Indiana. It differs from $C$. clussa in having a broader, flatter shell, and at no tume of life a dorsal keel. 
KEY TO THE GENERA OF INDIANA AMPHIBIANS AND REPTILES.

Body covered witl a smootl or warty skin; nu scales. Ampurbians. A. Body covered with scales or plates (except soft-shelled turtles, REPTILEs.

B.

\section{A. Ampindians.}

Provided with a distinct tail when adult, 1 . . . . . .

Adults without tails (frogs), 10

1. Adults with external gills, 2

1. Adults without gills, 3 .

2. Hinder limbs pesent. Necturus. . . . . . . . . .

3. With a small slit on each side of neck into throat; size large. CRYPTOBRANCHUS . . . . . . . . . . . . . . .

3. No slits along the neck; smaller, 4 . . . . . . . . . . .

4. No band of teeth running lengthwise in roof of mouth. AMBLYSTOMA

4. A single or double band of teeth running back in roof of mouth, 5 .

5. Tongue small, on a central stalk, free all around. \{ SPrLerpes.

5. Tungue rather large, attached by median band, free only at the sides and behind, 6 .

6. Toes behind four only; rare. Hemidacry

6. Toes behind five, 7 . . . . . . . . . .

7. With dots and eye-like spots above; belly red and dotted. DreMYCTYu's ......

7. Without eye-like spots; color uniform, dotted or banded, 8 . . . . .

8. Costal folds (grooves between fore and hind legs), 12; uniform black. Drsmognathes nigra . . . . . . . . . . . . . .

8. Costal folds 13 to 15,9

8. Costal folds 16 to 20 . Pufrionos erythronotus . . . . . . .

9. Black, with whitish dots and blotches. Pletrodon glutinosus. . . .

9. Brown, with marblings of pink or whitish. Desmognatrus fusca .

9. Yellowish brown, sides dusky, tail round. Desuognathus ochrophoca.

10. Upper jaw withnut teeth (toad). BUFo . . . . . . . . . .

10. Upper jaw with teeth, $11 \ldots \ldots$

11. Toes not terminating in dises, RANA. . . . . . . . . . .

11. Toes terminating is discs, sometimes small, 12 . . . . . . .

12. Dises large, fingers and toes webbed (tree frogs). HYLA . . . . .

12. Discs small, toes little webbed, size small. Chonopriuss. . . . . .

12. Dises small, toes broadly webbed, size small. ACrIs . . . . . . . .

\section{B. REPTHLES.}

1. Elongated animals, no limbs, belly covered with large scutes (snakes), 2

1. Moderately elongated animals with limbs (except Opheosaurus), belly covered with small scales, 15.

1. Slort bodied, broad animals, witl a carapace (turtles), 17.

2. Without poison fangs or a pit between eye and nostril, 3

2. With poison fang and a pit between eye and nostril, 14 .

3. With smooth scales, 4 .

3. With keeled scales, 7

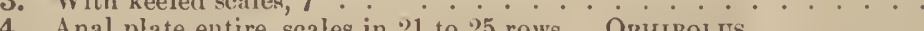

4. Anal plate entire, scales in 21 to 25 rows. Ornimolus. . . . . .

4. Anal plate divided, 5 .

5. Scales iu 23 rows, color brown or chestnut. Carpiropiris . . . .

5. Scales in 15 to 17 rows, color grayish brown, with a few dots, 6 
5. Scales in 19 rows, color bluish black, with red spots or f FARANCIA

stripes. . . . . . . . . . A Arastor.

6. Color yellowish brown, ventral scutes 115 to 123 . Virainia ...

6. Color black, with a yellowish collar. DiadopHis. . . . . . . . .

6. Color bright green. Cyclormis .............

7. Anal plate divided, 8 . . . . . . . . . . . . . .

7. Anal plate entire, 13 .................

8. Scales in 15 to 17 rows, 9 . . . . . . . . . . . . . .

8. Scales in 19 to 33 rows, 10 .

9. Color, green. Phrllopirlophis. . . . . . . . . .

9. Color, yellowish-brown or reddish. Storeria, p. 10, and Haldea p

10. Snout with a sharp, turned-up edge. IIETERonox........

10. Snont not as above, 11 . . . . . . . . . . . . . .

11. Ventral scutes 201) or more. Coluber . . . . . . . . . . . . . .

11. Ventral scutes 125 to 160,12

12. Belly usually pink or salmon, with two rows of black small spots. TroPIDOCLONIUM .

12. Belly not as above, colors in bauds lengtluwise, or in blotches (water-

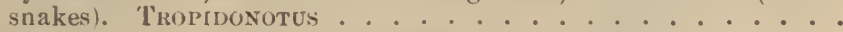

13. Scales in 17 rows. Tropidoclonium . . . . . . . . . . .

13. Scales in 19 to 21 rows, stripes lengthwise. Eutwist . . . . . . 10

13. Scales in 29 to 37 rows, speckled and blotched. Pitrophis . . . . . 10

14. Tail without rattle. Axcrstronon . . . . . . . . . . 13

14. Tail with rattle, top of head with large plates. CAubrsona. . . . 13

14. Tail with rattle, top of head with small scales. Crotalus . . . . 13

15. Without limbs, snakelike, but belly with small scales. OpHisaurus 14

15. With well-developed limbs, 16. ...........

16. With keeled scales, throat and sides deep blue or green. Sceloporus

16. Witl smootl scales, bronzy or grayish above, sides dusky. OLIGOSOMA.

16. With sinooth scales, blackish, gray or reddish, with five stripes and blue tail, or atripes indistinct and red head. EumEces . . . . . .

16. Witl smouth scales, color dark or gray, with 6 or 8 stripes. CNemiDOPIIORUS

17. Carapace and plastron without plates (soft-shell), 18 . . .

17. Carapace and plastron with distinct plates, 19 . . . . . . .

18. With a projecting ridge on nasal septum. Aspidonectes. . . . .

18. Without projecting ridge on nasal septum. AMYDA. . . . . .

19. Plastron with 12 plates, shell flaring more or less outward, highest in front or at the middle, 20

19. Plastron with 7 , !) or elercn plates, not flaring, highest behind, 26 .

20. Shell highest in frout, jaws stout and hooked (snapping turtle), 21

20. Shell highest in the middle (box and pond turtles), 22 .

21. Head with soft skin and no plates; tail witl two rows of large plates below, in the rniddle line; common. CrrelrorA. . . . . . . .

21. Head with symmetrical plates above; tail below, with many small overlapping scales; rare. Macrochelys. . . . . . . . .

22. Toes without a web, sliell high and capable of being closcly shut. Cistudo .

22. Toes with a narrow web; color black, with yellow dots. Curedopus

22. Toes broadly webbed, $\mathbf{2 3}$

23. Plastron with its lobes movable on transverse hinge; color jet black, with more or less yellow (Northern Ind.). EMYs.

23. Plastron large lobes not movable, hind legs largest, 24 .

24. Upper jaw not notched; carapace with a keel. MALACOcLimirs .

24. Upper jaw notched, shell of adult nut keeled, 25. . . . . . . . .

25. No ridge on grinding surface of the jaws; neck, legs and shell with more or less red. Chrysemys .

25. A conspicuous ridge on grinding surface of the jaws, stripes and spots on neck, legs and shell yellow and green. Pseudemys . . . . .

26. Both lobes of plastron movable on transverse hinge. Cinosternum .

26. Lobes of plastron little or not at all movable. Aвомоснитуs. . . .

Butler University, June 16, 1887. 
EXPLANATION OF PLATEI.

Fig. 1. The Brown Triton, Desmognathus fusca. P. 6.

1a. Open mouth of same species, showing teeth and tongue.

Fig. 2. Red-backed Salamander, Plethodon erythronotus, seen from above. P. 5.

Fig. 3. The Long-tailed Triton, Spelerpes lonyicrudus. P. 5.

Fig. 4. The Sinall-monthed Salamander, Amblystoma microstomum, showing the vomerine teeth and the tongue with a median furrow. P. 4.

Fig. 5. The Slimy Lizard, Plethodon glutinosus, showing the open mouth with tongue and teeth. P. 5.

Fig. 6. The Marbled Salamander, Amblystoma opacum. P. 4.

Fig. 7. The Tiger Salamander, Amblystoma tigrinum. 1'. 4.

Fig. 8. The Green Triton, Diemyctylus viridescens. P. 6.

8a. Open mouth of same, showing small tongue and two rows of teeth. All the figures were drawn from alcoholic specimens and represent the natural size. 
PLATE I.
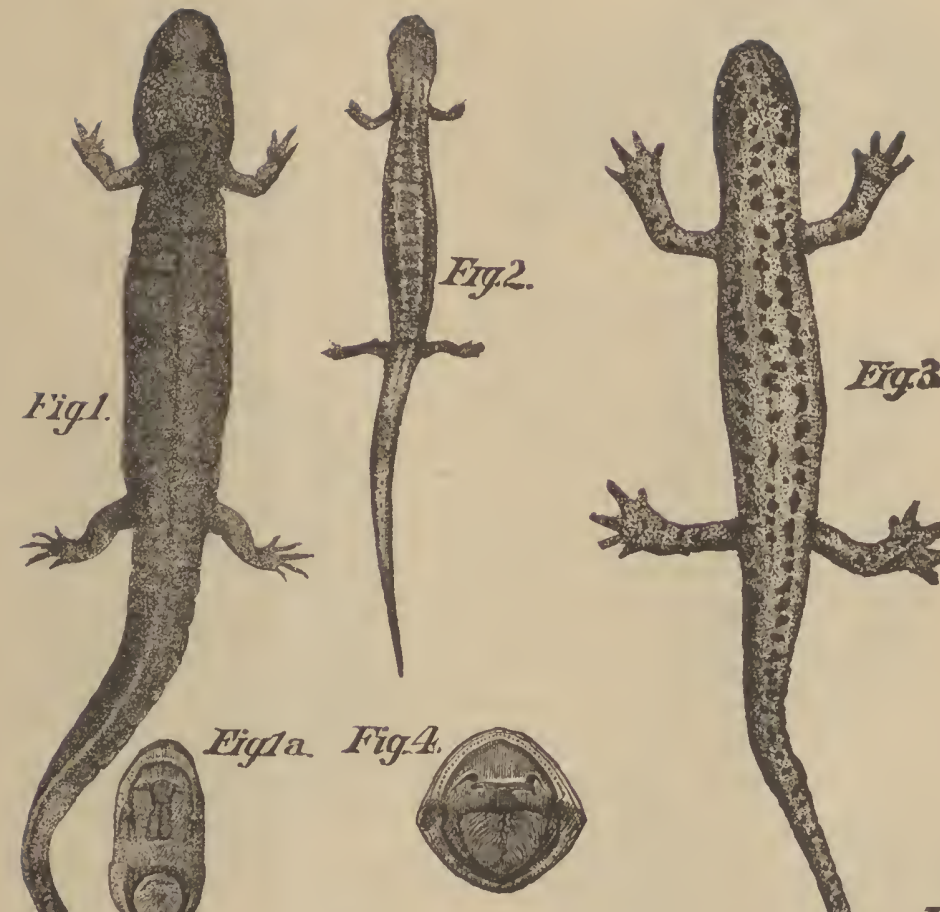

righs.
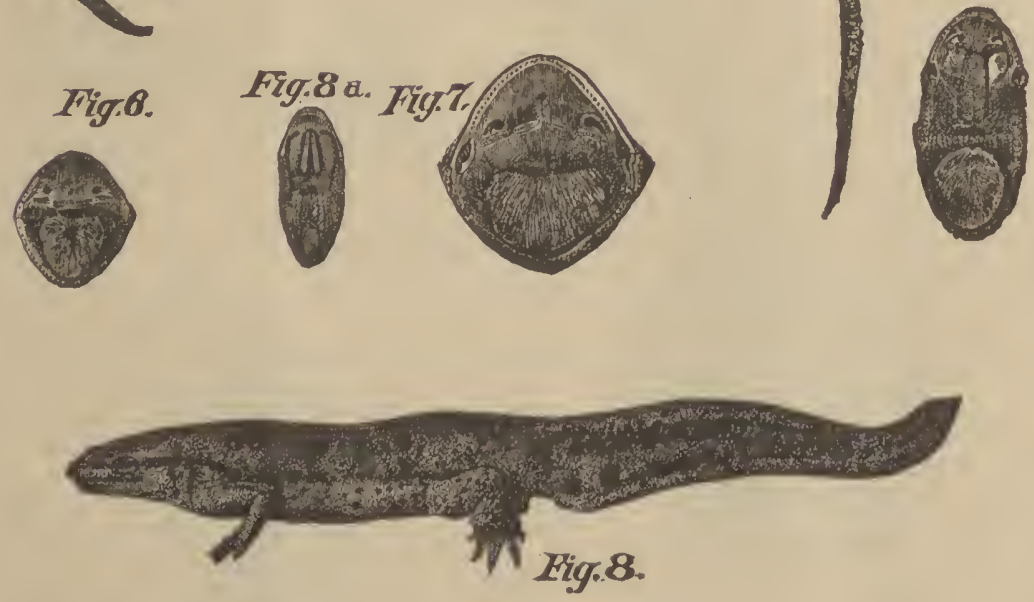


\section{FXPLANATION OF PLATE II.}

Fig. 9. The Striped 'Tree-Frog, Chorophilus triseriatus, natural size. P. 6.

Fig. 10. Le Sueur's Terrapin, Malacoceminys lesueurii, natural size of the very young. P. 16.

Fig. 11. The Musk Turtle, Aromochelys odoratus, shell seen from below, one-half natural size. P. 15.

Fig. 12. The Mud Turtle, Cinosternum pennsyloanicum, from below, one-half natural size. P. 16.

Figs. 13 and 13a. Side and upper views of Helen's Snake, Carphophis helenc, twice natural size. P. 8 .

Figs. 14 and 14a. Side and upper views of the Sand Viper, Heterodon simus, natural size. P. 12.

Fig. 15. Upper view of head of Prairie Kattlesnake, Caudisona tergemina, natural size. P. 13.

Fig. 16. Upper view of head of Banded Rattlesnake, Crotalus homidus, natural size. P. 13 .

Fig. 10 has been re-drawn from Agassiz; Fig. 16 has been adapted from a figure by S. Cxarman; all the others were drawn from nature. 
PLATE II.
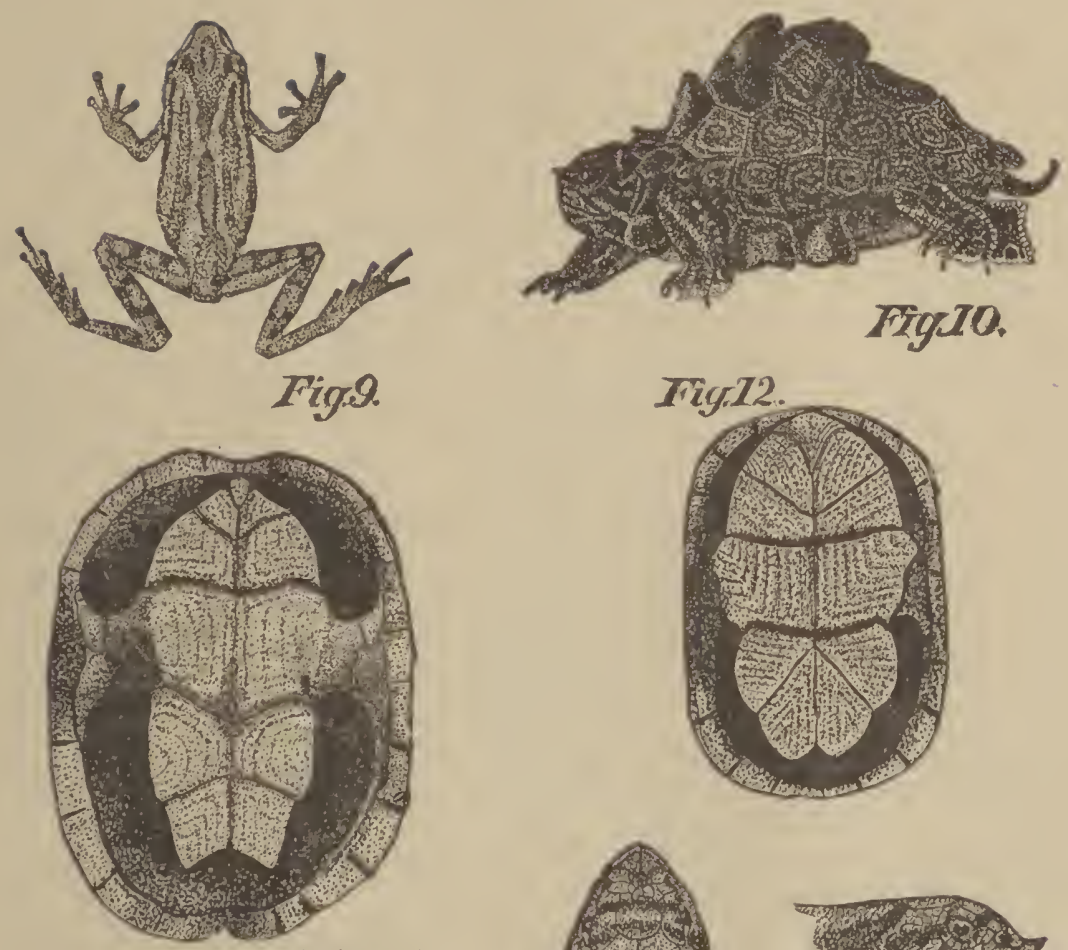

Figll.

Fuy.12.
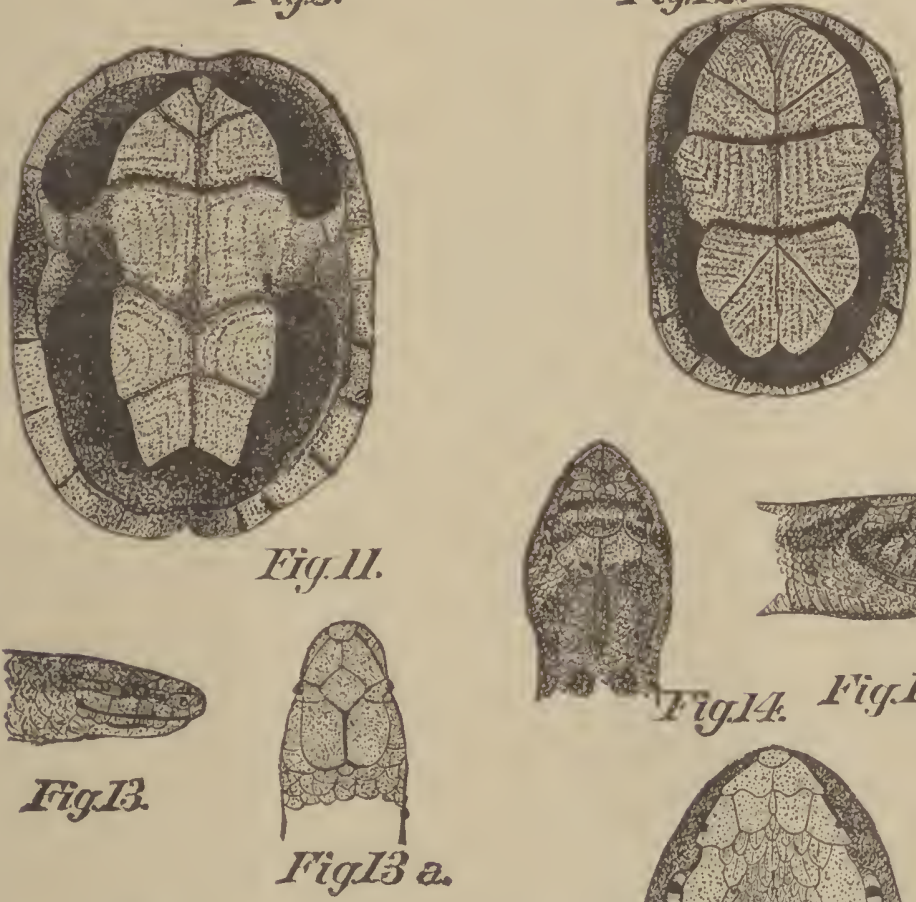

Fig I3.

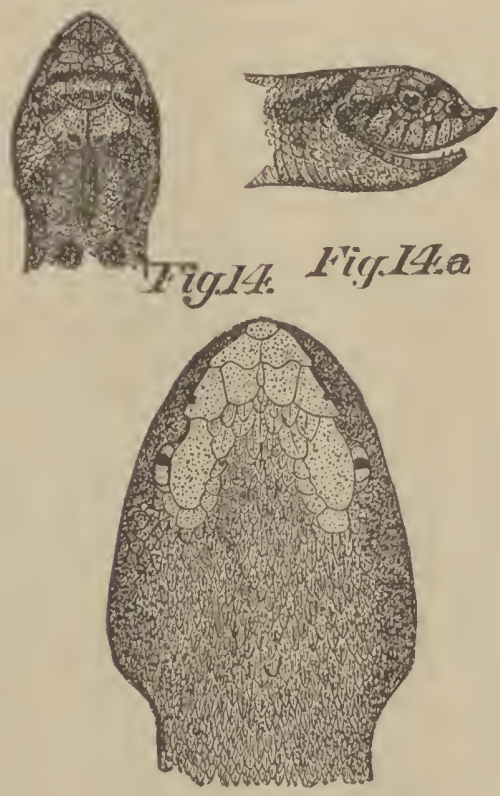

Figit6.

Fig.15.

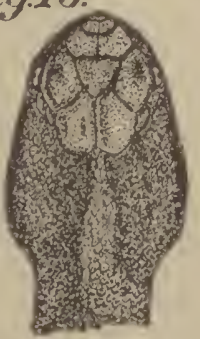


